AWEJ for Translation \& Literary Studies, Volume3, Number4. October 2019

DOI: http://dx.doi.org/10.24093/awejtls/vol3no4.6

Pp. 61-85

\title{
The Pragmatics of Romance in the First World War' Poetry
}

\author{
Jinan Kadhim Isma'eel \\ English Department, College of Education for Women \\ University of Baghdad. Iraq \\ Rufaidah Kamal Abdulmajeed \\ English Department, College of Education for Women \\ University of Baghdad. Iraq
}

\begin{abstract}
Many influences have shaped literature; war is one of them. Among the horrors, death tolls, destructions, and chaos, there should be inevitably a beam of light of hope, a desirous and eagerness for long life, expressions of love, loyalty to the homeland and other feelings that carry a sense of romance in different shapes. This study hypothesized that romance is found in war poetry, and it has various meanings other than the conventional definition; the scope of the meanings of the word romance is either expanded or shrunk. The expansion happens throughout the appearance of new meanings. They were not there before or after this time. The shrinking happens when some of the meanings are vanished and no longer used as a denotation of romance. These meanings are realized in various pragmatic devices. The war poems selected for this study are Rupert Brooke's The Soldiers and Allan Seeger's I Have a Rendezvous with Death. The results show that romance has (34) meanings. Of them, is 'Idealization' and 'heroism'; which score the highest frequency and appear (5) times equal to (31\%); 'Love and intimacy' comes next with (3) times equal to (19\%); 'Bravery' scores (2) times equal to (13\%); and finally 'Patriotism' registers the lowest frequency with (1) time, equal to $(6 \%)$. The pragmatic devices that realize these meanings and that register the highest frequencies are: hyperbole, personal deixis, enumeration, and metonymy.
\end{abstract}

Keywords: Allan Seeger, First World War, pragmatics, romance, Rupert Brooke, war poetry

Cites as: Jinan Kadhim Isma'eel, J. K., \& Abdulmajeed, R. K. (2019). The Pragmatics of Romance in the First World War' Poetry. Arab World English Journal for Translation \& Literary Studies3 (4) . DOI: http://dx.doi.org/10.24093/awejtls/vol3no4.6 